\title{
The potential of the synergistic use of passive and active remote sensing measurements for the validation of a regional dust model
}

\author{
V. Amiridis ${ }^{1}$, M. Kafatos ${ }^{2}$, C. Perez ${ }^{3}$, S. Kazadzis ${ }^{4,8}$, E. Gerasopoulos ${ }^{4}$, R. E. Mamouri ${ }^{5}$, A. Papayannis ${ }^{5}$, P. Kokkalis ${ }^{5}$, \\ E. Giannakaki ${ }^{6}$, S. Basart ${ }^{3}$, I. Daglis ${ }^{1}$, and C. Zerefos ${ }^{7}$ \\ ${ }^{1}$ Institute for Space Applications and Remote Sensing, National Observatory of Athens, Athens, Greece \\ ${ }^{2}$ Center of Excellence in Earth Observing, Schmid College of Science, Chapman University, California, USA \\ ${ }^{3}$ Barcelona Supercomputing Center-Centro Nacional de Supercomputación (BSC-CNS), Earth Sciences Department, \\ Barcelona, Spain \\ ${ }^{4}$ Institute of Environmental Research and Sustainable Development, National Observatory of Athens, Athens, Greece \\ ${ }^{5}$ Laboratory of Lasers and Applications, National Technical University of Athens, Athens, Greece \\ ${ }^{6}$ Laboratory of Atmospheric Physics, Aristotle University of Thessaloniki, Thessaloniki, Greece \\ ${ }^{7}$ Laboratory of Climatology, University of Athens, Athens, Greece \\ ${ }^{8}$ Finnish Meteorological Institute, Climate Change Unit, Helsinki, Finland
}

Received: 30 March 2009 - Revised: 23 July 2009 - Accepted: 11 August 2009 - Published: 12 August 2009

\begin{abstract}
A long-lasting Saharan dust event affected Europe on 18-23 May 2008. Dust was present in the free troposphere over Greece, in height ranges between the surface and approximately $4-5 \mathrm{~km}$ above sea level. The event was monitored by ground-based CIMEL sunphotometric and multi-wavelength combined backscatter/Raman lidar measurements over Athens, Greece. The dust event had the maximum of its intensity on 20 May. Three-dimensional dust spatial distribution over Greece on that day is presented through satellite synergy of passive and active remote sensing using MODIS and CALIPSO data, respectively. For the period under study, the ground-based measurements are used to characterize the dust event and evaluate the latest version of the BSC Dust Regional Atmospheric Modeling (BSC-DREAM) system. Comparisons of modeled and measured aerosol optical depths over Athens show that the Saharan dust outbreak is fairly well captured by BSC-DREAM simulations. Evaluation of BSC-DREAM using Raman lidar measurements on 20 May shows that the model consistently reproduces the dust vertical distribution over Athens.
\end{abstract}

Keywords. Atmospheric composition and structure (Aerosols and particles; Pollution - urban and regional; Instruments and techniques)

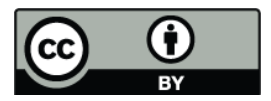

Correspondence to: V. Amiridis (vamoir@space.noa.gr)

\section{Introduction}

The Mediterranean area is strongly affected by the presence of desert dust due to its proximity to North Africa. Limitations on the description of the dust cycle are mainly related to the lack of enough dense and regular measurements, but also due to the incomplete understanding of dust processes such as production, transport, physical and chemical evolution, optical properties and removal of dust (Sokolik et al., 2001). Several regional models for simulation and prediction of the atmospheric dust cycle have been developed over the past decade (e.g., Kallos et al., 1997; Nickovic et al., 2001). These models are essential to complement dust-related observations and to understand the dust cycle. In this context, the BSC Dust Regional Atmospheric Model (BSC-DREAM) (Nickovic et al., 2001; Perez et al., 2006a, b) has reached a level of delivering reliable operational dust forecasts (http:// www.bsc.es/projects/earthscience/DREAM/) capable of predicting all the major dust events over the Mediterranean region. However, the current operational version still has large development possibilities.

In order to implement new model versions for operational applications there is a need for extensive checking and validation with observations. Nowadays, ground-based monitoring systems include conventional surface observations operating at urban and rural areas. Long range transport of desert dust mainly takes place in the free troposphere (e.g. Mattis et al., 2002; Ansmann et al., 2003). Thus sun photometers delivering spectrally resolved column-integrated data in combination with aerosol lidar instruments providing

Published by Copernicus Publications on behalf of the European Geosciences Union. 
information on the vertical structure seem the most appropriate tools for such model evaluation studies.

Sun photometry, with variable measurement approaches has been developed in recent years to deduce the variability of critical atmospheric aerosol properties. The AErosol RObotic NETwork (AERONET) program is a federated remote sensing network of well-calibrated sun photometers and radiometers located at over 200 sites covering all major tropospheric aerosol regimes around the world (Holben et al., 1998). AERONET stations provide columnar aerosol optical parameter information (aerosol optical depth, size distribution, single scattering albedo etc.) through direct measurements and inversion techniques. These data constitute a highquality, ground-based aerosol climatology and, as such, have been widely used for aerosol process studies, as well as for evaluation and validation of model simulations. However, it should be noted that most inversion-based retrieval products have not yet been systematically validated. In addition, no information is provided regarding the vertical distribution of aerosol properties, which is a limitation.

Lidar is the only technique that provides high resolution vertical profiling of aerosols. In recent years, Raman Lidars and micro-pulse Lidars (MPL) have been increasingly used to automatically and routinely retrieve profiles of aerosol backscattering and extinction. The European Aerosol Research Lidar NETwork (EARLINET) was established in 2000 to characterize the horizontal, vertical, and temporal distribution of aerosols on a European scale (Bösenberg et al., 2003). At present, EARLINET consists of 25 stations, including backscatter lidar stations, 16 combined backscatter/Raman lidar stations and 8 multi-wavelength Raman lidar stations which are used to retrieve aerosol microphysical properties.

Lidar techniques play an increasing role in future Earth observation strategies. CALIOP (Cloud-Aerosol LIdar with Orthogonal Polarization) onboard the NASA/CNRS CALIPSO satellite provides a first opportunity to study in detail the performance and the scientific value of a space-borne aerosol lidar during a long term mission. CALIOP lidar onboard CALIPSO, provides information on the vertical distribution of aerosols and clouds as well as on their optical properties over the globe with unprecedented spatial resolution (Winker et al., 2006). However, CALIPSO observations provide global, but snapshot-like view of aerosol vertical distributions. Only combined studies with ground-based lidars together with transport modeling techniques will allow a full exploitation of these data for a detailed description of the temporal and spatial aerosol distribution and evolution on a global scale. Active and passive remote sensing satellite data synergy on the other hand can improve aerosol characterization and speciation. CALIPSO active remote sensing data can be used in conjunction with the MODerate resolution Imaging Spectroradiometer (MODIS) (e.g. Remer et al., 2008) to better indentify and characterize aerosol distributions and properties.
In this study, the spatial and temporal evolution, optical properties and vertical structure of the Saharan dust plume that affected Europe between 18-23 May 2008 as estimated by the BSC-DREAM dust modeling system are validated over Greece using synergistic passive and active remote sensing techniques. First, we describe the Saharan dust outbreak over Greece using the latest updated version of BSCDREAM and satellite imagery from SEAWIFS. The threedimensional structure of dust outflow over Greece is then presented as retrieved by MODIS and CALIPSO aerosol data for a selected day when dust load over Greece showed maximum values. Qualitative evaluation of the evolution of the modeled dust horizontal and vertical structure is performed. Satellite/ground-based data and modeling results are used to identify cases with pure dust presence in the free troposphere over Athens. Then, the columnar and vertical evolution and the optical properties of the dust plume measured with ground-based instrumentation are analysed together with BSC-DREAM dust modeling estimations. The main objective of the study is to present and formulate potential methods to validate a dust modeling system using new and well-known active and passive remote sensing techniques from space and ground. The driving force behind this study is the fact that aerosols over the Eastern Mediterranean region originate from different sources, including a marine component (mainly sea spray), a mineral dust component mainly due to the proximity to Saharan desert dust and an anthropogenic component (local and long-range pollution) (Mihalopoulos et al., 1997; Papayannis et al., 2005, 2008; Formenti et al., 2001; Lelieveld et al., 2002; Zerefos et al., 2002; Gerasopoulos et al., 2003; Balis et al., 2004; Amiridis et al., 2005, Kazadzis et al., 2007; Kalivitis et al., 2007; Fotiadi et al., 2006), demanding strong data synergy for aerosol speciation. After the identification of pure dust presence, model validation studies can become more quantitative and accurate.

\section{Instrumentation and methods}

\subsection{CIMEL sunphotometer}

The sunphotometric observations reported in this paper were performed by a CIMEL sun-sky radiometer, which is part of the Aerosol Robotic Network (AERONET) Global Network (http://aeronet.gsfc.nasa.gov). The instrument is located on the roof of the Research Center for Atmospheric Physics and Climatology of the Academy of Athens $\left(37.99^{\circ} \mathrm{N}, 23.78^{\circ} \mathrm{E}\right.$, elevation: $130 \mathrm{~m})$. The campus is located in the city center and $10 \mathrm{~km}$ from the sea. This newly installed sunphotometric station is operated by the Institute for Space Applications and Remote Sensing (ISARS) of the National Observatory of Athens (NOA). The technical specifications of the instrument and AERONET data products are given in detail in Holben et al. (1998). 


\subsection{Ground-based lidar system}

The NTUA compact 6-wavelength Raman lidar system is based on a pulsed Nd:YAG laser emitting simultaneously at $355 \mathrm{~nm}, 532 \mathrm{~nm}$ and $1064 \mathrm{~nm}$. The elastically backscattered lidar signals (at 355, 532 and $1064 \mathrm{~nm}$ ), as well as those generated by Raman scattering by atmospheric $\mathrm{N}_{2}$ and $\mathrm{H}_{2} \mathrm{O}$ (at 387, 607 and $407 \mathrm{~nm}$, respectively) are simultaneously recorded by photomultipliers (PMTs) and avalanche photodiode systems (APD), after the spectral separation of the returned lidar signals (Mamouri et al., 2009; Papayannis et al., 2005). The system is used to perform continuous measurements for the retrieval of the aerosol optical properties over Athens inside the Planetary Boundary Layer (PBL) and the lower free troposphere. In the frame of the EARLINET and EARLINET-ASOS projects, the NTUA lidar system was quality assured by performing direct intercomparisons, both at hardware (Matthias et al., 2004) and software level (Böckmann et al., 2004; Pappalardo et al. 2004). The lidar system of NTUA is located within $400 \mathrm{~m}$ distance from the CIMEL sunphotometer.

\subsection{Satellite measurements}

The Cloud-Aerosol Lidar and Infrared Pathfinder Satellite Observation (CALIPSO) mission (http://smsc.cnes.fr/ CALIPSO/), is an Earth Science observation mission that launched on 28 April 2006 and flies in nominal orbital altitude of $705 \mathrm{~km}$ and an inclination of 98 degrees as part of a constellation of Earth-observing satellites known as the "Atrain" (Hostetler et al., 2001). The CALIPSO mission provides crucial lidar and passive sensors to obtain unique data on aerosol and cloud vertical structure and optical properties. CALIPSO is an elastically backscattered lidar operating at 532 and $1064 \mathrm{~nm}$, equipped with a depolarization channel at $532 \mathrm{~nm}$, that provides high-resolution vertical profiles of aerosols and clouds (Winker et al., 2006). The Level 1 V2 (Version 2) attenuated backscatter and depolarization profile product is used in this paper.

Finally, the Moderate Resolution Imaging SpectroRadiometer (MODIS) aerosol 5-min level-2 swaths (collection 5) were retrieved through NASA's Earth Observing System Data Gateway. AOD values at $550 \mathrm{~nm}$ were extracted with an uncertainty of $\pm 0.05 \pm 0.15^{*} \mathrm{AOD}$ over land (Remer et al., 2008).

Summarizing, we have used a synergy of different remote sensing instruments and techniques to derive a variety of dust aerosol optical properties. From measurements at the ground we have retrieved AOD, Angstrom parameters, aerosol size distribution and single scattering albedo and also lidar backscatter and extinction coefficient profiles at UV and visible wavelengths. In addition AOD, total attenuated backscatter coefficient aerosol profiles and images in the visible have been retrieved from satellite sensors.

\subsection{The BSC-DREAM model}

DREAM (Nickovic et al., 2001) is a regional model designed to simulate and/or predict the atmospheric cycle of mineral dust aerosol. The Barcelona Supercomputing Center maintains dust forecast operations with DREAM and conducts modelling research and developments for short-term prediction. During model integration, calculation of the surface dust injection fluxes is made over the model grid points declared as deserts. Once injected into the air, dust aerosol is driven by the atmospheric model variables: by turbulent parameters in the early stage of the process when dust is lifted from the ground to the upper levels; by model winds in the later phases of the process when dust travels away from the sources; finally, by thermodynamic processes (atmospheric water phase changes producing clouds, rain and dust wet scavenging) of the atmospheric model and land cover features which provide wet and dry deposition of dust over the Earth surface.

One of the key components of the dust model is the treatment of the source terms in the concentration continuity equation. Failure to adequately simulate/predict the production phase of the dust cycle leads to wrong representation of all other dust processes in the model. Therefore, special attention is made to properly parameterize dust production phase. The dust emission parameterization in the model is controlled mainly by the following factors: type of soil, type of vegetation cover, soil moisture content, and surface atmospheric turbulence. In the model, grid points acting as desert dust sources are specified using arid and semiarid categories of the global USGS 1-km vegetation dataset. Another data participating in dust production calculations is the FAO 4$\mathrm{km}$ global soil texture data set from which particle size parameters are evaluated. The main general features of the last version of the model (Perez et al., 2006a) used in this study are listed below:

- Dust production scheme with introduced viscous sublayer (Shao et al., 1993; Janjic, 1994)

- 8 particle size bin distribution.

- Soil wetness effects on dust production (Fecan et al., 1999)

- Dry deposition (Giorgi, 1986) and below cloud scavenging.

- Horizontal and vertical advection, turbulent and lateral diffusion (Janjic, 1994) represented as for other scalars in the Eta/NCEP model.

- Dust radiative feedbacks on meteorology (Pérez et al., 2006a).

Eight size bins between 0.1 and $10 \mu \mathrm{m}$ are considered in the dust transport process. In this interval, the aerosol effects on 
BSC/DREAM (12 UTC): Dust Loading $\left(\mathrm{gr} / \mathrm{m}^{2}\right)$ and $3000 \mathrm{~m}$ wind
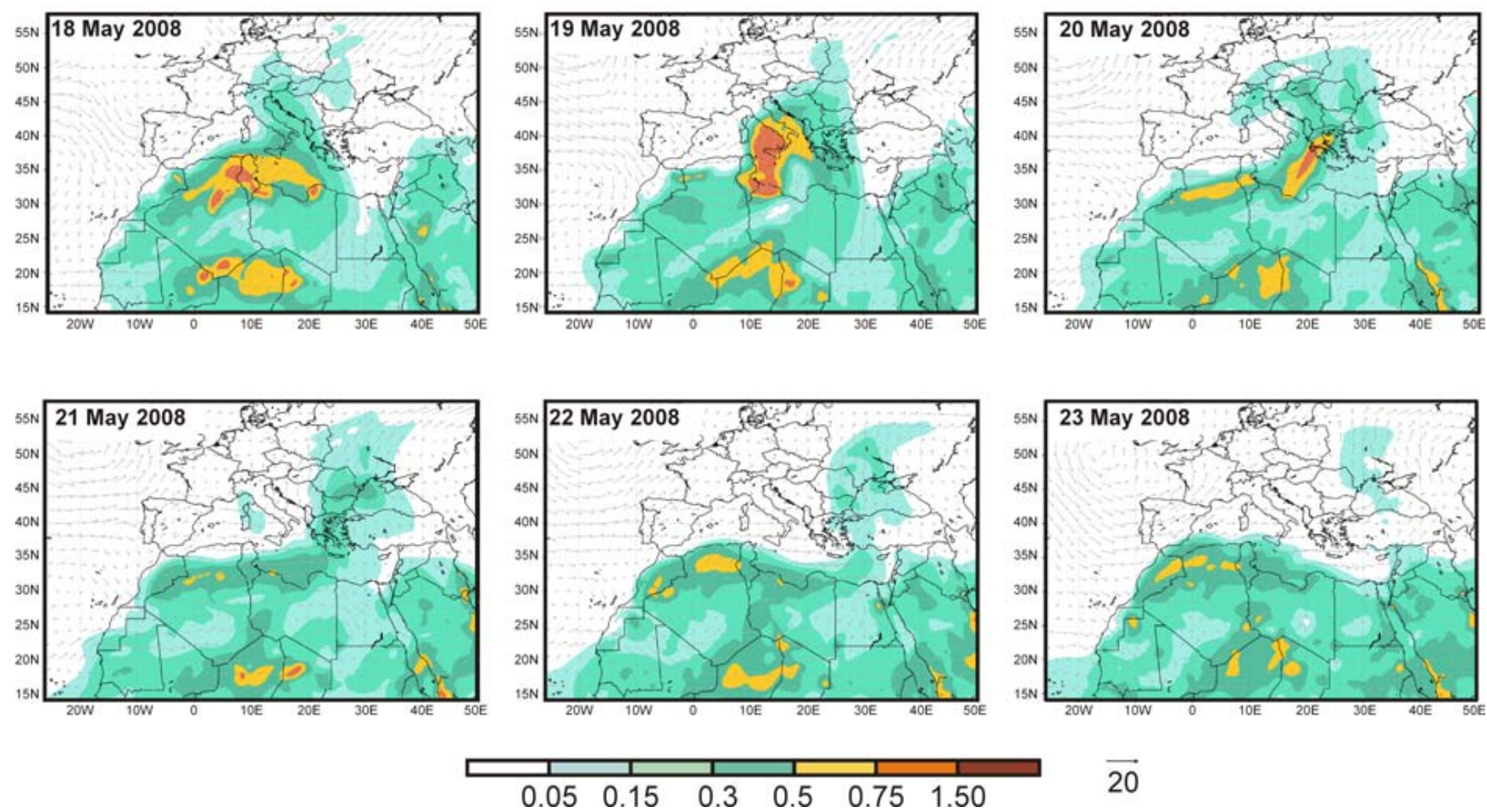

Fig. 1. Dust loading and $3000 \mathrm{~m}$ wind fields over Europe for the period 18-23 May 2008, as estimated by the BSC-DREAM model (12:00 UTC).

solar radiation are the most significant. Within each transport bin, dust is assumed to have time-invariant, sub-bin lognormal distribution employing the transport mode with mass median diameter of $2.524 \mu \mathrm{m}$ and geometric standard deviation 2.0. The analytic sub-bin distribution allows accurate prescription of physical and optical properties known to vary across the bin width.

The model at the starting day is run using "cold start" conditions, i.e., the zero-concentration initial state. The model needs about 2-3 days for spinning up and for establishing reliable dust concentration conditions. The cold start of the model was initiated on the 14 May 2008. The resolution is set to $50 \mathrm{~km}$ in the horizontal and to 24 layers extending up to approximately $15 \mathrm{~km}$ in the vertical. Meteorological fields are initialized every $24 \mathrm{~h}$ and boundary conditions updated every $6 \mathrm{~h}$ with the NCEP/NCAR I global analysis ( 1 degree $\times 1 \mathrm{de}-$ gree resolution). The choice of 24 -h re-initialization is used to avoid introducing large discontinuities in the simulation (in contrast to 48-h or $72 \mathrm{~h}$ ) while letting the model develop its own dynamics and physics. The domain of simulation covers northern Africa, the Mediterranean Sea, and southern Europe (Fig. 1).

\section{Results and discussion}

\subsection{Evolution of dust over Greece during 18-23 May 2008}

A long-lasting Saharan dust event affected Europe from 1823 May 2008. Such events in terms of length and concentrations of transported dust load are limited during each year for the particular area. In addition, it was the first time that such an event could be captured by all instruments used in this work for Athens area. The BSC-DREAM model estimations of the spatial evolution of dust in terms of vertical integrated dust concentration $\left(\mathrm{gr} / \mathrm{m}^{2}\right)$ are presented in Fig. 1. Additionally, the wind fields at $3000 \mathrm{~m}$ are superimposed. None of the days presented were accompanied by precipitation or severe cloud conditions over Greece. The massive export of dust from the Sahara is observed on 18 May over Italy and Central Europe while on 19 May the center of the dust plume spread over eastern parts of Europe. On 20 May, the dust plume covers Greece and the dust load reached values of $\sim 0.75 \mathrm{gr} / \mathrm{m}^{2}$. The dust concentrations over Europe gradually reached smaller values on the following days, even if dust particles were still present in the free troposphere as the BSC-DREAM model indicates. Concerning the qualitative performance of the model, the spatial patterns of the 

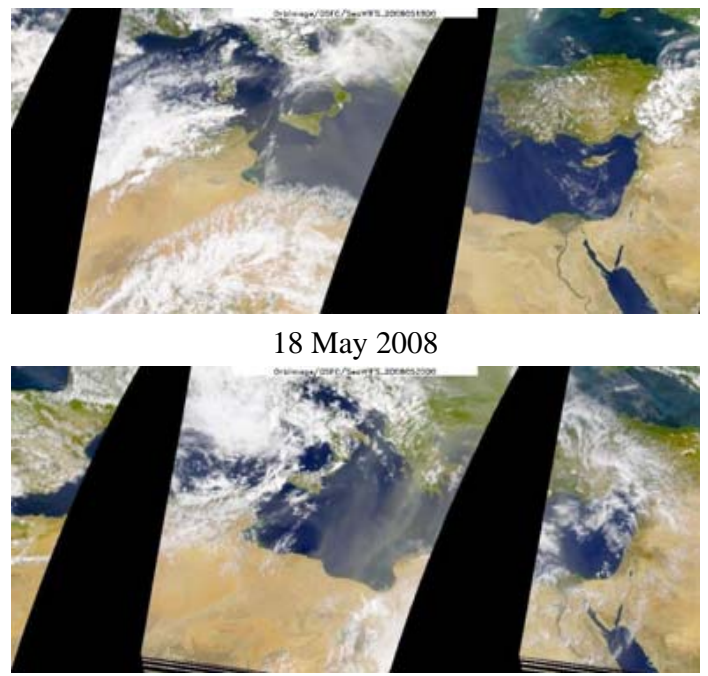

20 May 2008

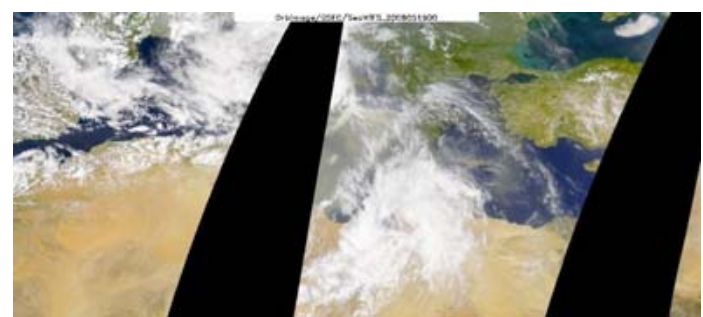

19 May 2008

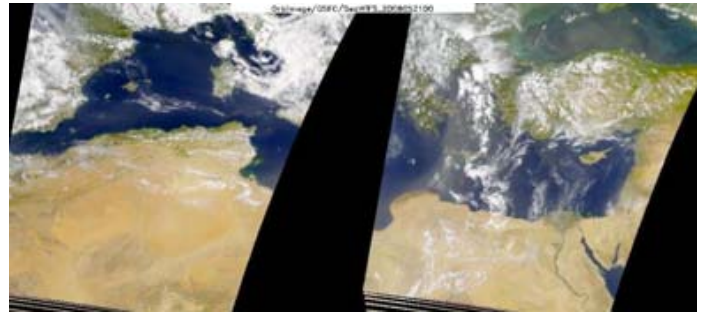

21 May 2008

Fig. 2. SeaWIFS visible satellite images for 18, 19, 20 and 21 May 2008.

dust plume show very good agreement with the corresponding Seawifs visible satellite images (Fig. 2).

For 20 May, according to the model simulation (shown in Fig. 1), Greece was mostly affected by dust aerosols. In Fig. 3 we present satellite aerosol data from the MODIS and CALIPSO space-borne instruments. The AODs at $550 \mathrm{~nm}$ are plotted over Greece, taken by MODIS aerosol 5-min level-2 swaths (collection 5) at 09:55 UTC. Dust AOD values for Greece on 20 May 2008 according to the model (shown in Fig. 1) range between 0.15-0.75 at 12:00 UTC. Concerning the qualitative performance of the model, the spatial patterns of the dust plume show that the AOD values retrieved by MODIS at $550 \mathrm{~nm}$ are higher than AODs estimated by the model, and this is attributed to the contribution of the anthropogenic local pollution. This is expected since model delivers AODs concerning only dust. In Fig. 3, the CALIPSO vertical cross section of the attenuated backscatter coefficient at $532 \mathrm{~nm}$ is superimposed for 20 May at 09:50 UTC. According to CALIPSO observations the dust presence in the vertical is extended to the free troposphere over Greece up to heights of 3000-5000 m. This argument is moreover supported by CALIPSO's depolarization measurements at $532 \mathrm{~nm}$ (not shown here). The depolarization ratio on 20 May reached values in the range between $0.3-0.7$ indicating the presence of dust particles in the free troposphere over Greece. Few white out regions in the Fig. 3 indicate CALIOP aerosol retrievals that were affected by clouds.

\subsection{Characterization of the dust event using the CIMEL sunphotometer and NTUA's lidar}

To characterize the dust properties over Athens for 20 May 2008, ground-based sun photometric and combined
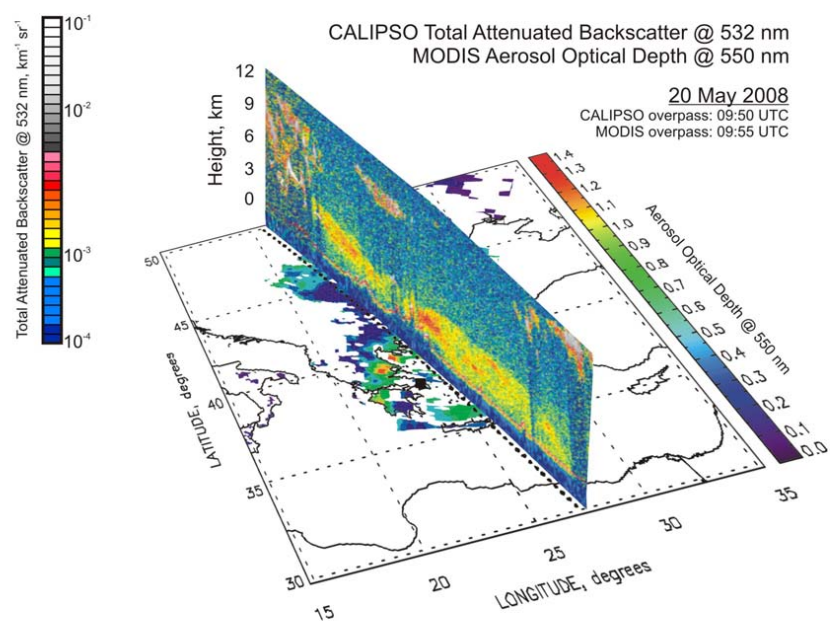

Fig. 3. Three-dimensional representation of dust evolution over Greece for 20 May 2008. Spatial distribution of AOD obtained at $550 \mathrm{~nm}$ by the MODIS sensor and CALIPSO cross section of the attenuated backscatter coefficient at $532 \mathrm{~nm}$.

backscatter/Raman lidar measurements are used in this study. From the direct CIMEL sunphotometric measurements over Athens, the AOD at selected spectral channels is derived, following the well-known Beer-Bouguer-Langley law. The Ångström exponent $(\alpha)$ is derived according to the Ångström power law, using the 440, 670 and $870 \mathrm{~nm}$ channels (e.g. Eck et al., 1999). The data are processed within the AERONET version 2 direct Sun algorithm, which is described in detail on the AERONET web page. Such data define the aerosol climatology of the site (Holben et al., 2001). From the almucantar sky radiance measurements at the four highest 


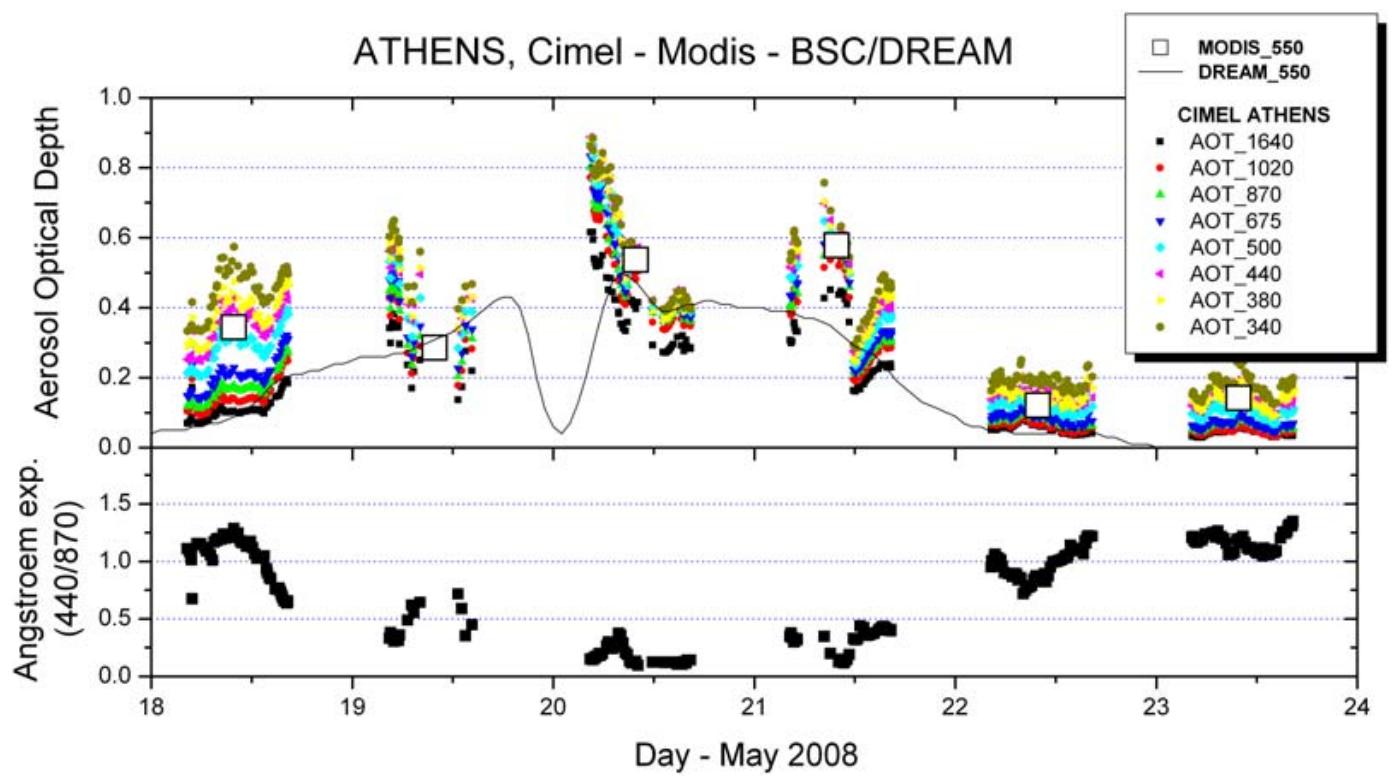

Fig. 4. Temporal evolution of the AOD at eight wavelengths over Athens for the period 18-23 May 2008 according to CIMEL sunphotometric measurements, MODIS AOD at $550 \mathrm{~nm}$ (white squares) and BSC-DREAM dust AOD at $550 \mathrm{~nm}$ (upper panel). Temporal evolution of the Ångström exponent $(440-870 \mathrm{~nm})$ for the same time period (lower panel).

wavelengths an inversion algorithm (AERONET version 2 (Dubovik et al., 2002, 2006)) retrieves a large set of optical and microphysical aerosol parameters. In Fig. 4 we present the temporal evolution of the AOD and the Ansgtröm exponent $(\alpha)$ over the Athens AERONET site, as well as the MODIS AODs at $550 \mathrm{~nm}$ which are found to be in good agreement with CIMEL measurements. Additionally, BSCDREAM AODs for dust are plotted, showing that the evolution of the episode is well captured by the model. Figure 4 shows the quick arrival of the desert plume at Athens station (the AOD increases significantly from 18 May to 20 May). The highest AOD is registered on 20 May with a value of 0.8 $(440 \mathrm{~nm})$. The desert dust plume is also visible on 21 May, while the following days (22-23 May) show a clear weakening of the event as the desert plume quickly moved away, as shown by the AOD, which dropped back to background levels.

In Fig. 4 we can also observe the time series of the Ånsgtröm exponent, which shows very low values (from zero to 0.5 ) for 19, 20 and 21 May, in inverse correspondence with the high AOD for desert aerosols. One of the characteristics of the desert dust episodes is the high variability shown by both parameters during each day. As can be seen in Fig. 4, on 19 May partial cloudiness is observed and some data were removed by the AERONET cloud-screening algorithm. On 20 May at 00:00 UTC, a strong dust layer is advected away from the observation location accounting for the sudden drop of the AOD. The analysis of the dust model maps at that time (not shown here) essentially explains this sudden drop. For the period between 18 and 22 May, the mean daily Volume Size Distribution (not shown here but can be found on the AERONET web page: http://aeronet. gsfc.nasa.gov/cgi-bin/type_one_station_opera_v2_new?site= ATHENS-NOA $\backslash \&$ nachal $=2 \backslash \&$ level $=2 \backslash \&$ place_code $=10$ ) exhibit two modes, but the relative importance of the modes depends on the prevailing aerosol type: an accumulation or fine mode with particle radius below $0.6 \mu \mathrm{m}$, and a coarse mode with particle radius between 0.6 and $15 \mu \mathrm{m}$. In this case, obviously we expect a predominant coarse mode during desert dust conditions. The mode radii and volume concentrations were analyzed in order to characterize the aerosol dust evolution. The evolution of the desert dust is clear in the coarse mode fraction. The Volume Size Distribution exhibits well defined desert dust characteristics from 19 to 21 May with more predominant effects for 20 May when the volume concentration peaks varying from 0.9 to $1.6 \mu \mathrm{m}^{3} / \mu \mathrm{m}^{2}$ with a mean of $1.4 \mu \mathrm{m}^{3} / \mu \mathrm{m}^{2}$.

From the backscatter lidar measurements performed over Athens on 20 May 2008, time-height cross section of the lidar range corrected signals at $532 \mathrm{~nm}$ are presented in Fig. 5. According to lidar observations, there are two distinct aerosol vertical structures evolving during the day under study. The first layer, which corresponds to the PBL, is well located between the surface and $2500 \mathrm{~m}$ in the morning hours, showing a descent at around 13:00 UTC. During the afternoon and night-time measurements, the top of the layer is located in height ranges between $2000-2700 \mathrm{~m}$. The second layer is located in the free troposphere well above PBL, reaching high backscatter signal values during the day and mostly during afternoon hours. In nighttime, 


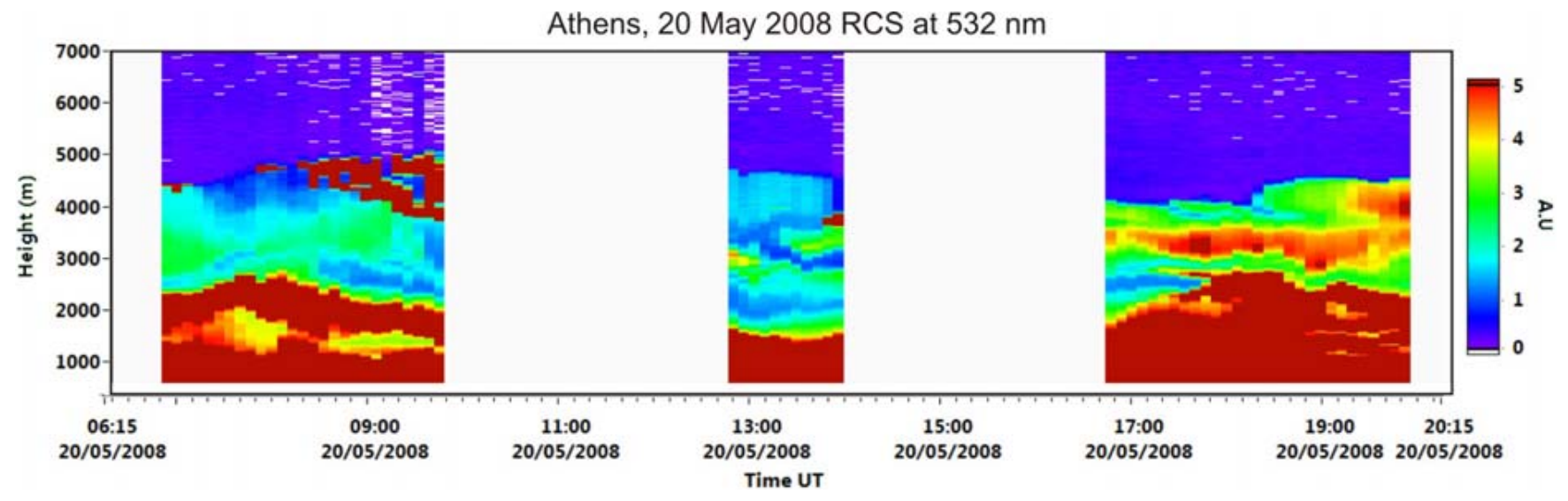

Fig. 5. Time-height cross section of the lidar range corrected signal at $532 \mathrm{~nm}$ (arbitrary units) measured on 20 May 2008 over Athens.

this layer is located between the top of the PBL and approximately $5000 \mathrm{~m}$. Given the BSC-DREAM simulations and CALIPSO's depolarization ratio values presented above, this layer is completely attributed to Saharan dust aerosols advected over Athens. High values of the backscatter signals within the PBL indicate the possibility of dust presence also in lower heights.

\subsection{Validation of BSC-DREAM simulations}

In our study, an attempt to validate BSC-DREAM model simulations is made using the ground-based passive and active remote sensing measurements presented previously. We use sunphotometric measurements for the complete period of the dust outbreak, while for the lidar case we focus on the case study of 20 May when dust load was clearly present over Athens and night-time Raman measurements were available.

In Fig. 6, we present the AODs measured by CIMEL versus the dust AODs estimated by BSC-DREAM, for the period under study. BSC-DREAM delivers AODs at $550 \mathrm{~nm}$ and CIMEL at $500 \mathrm{~nm}$. For a direct comparison, CIMEL AODs where converted from 500 to $550 \mathrm{~nm}$ using the Ångström exponent (440/870). The correlation coefficient found to be of the order of 0.7, showing a quite good agreement between BSC-DREAM and CIMEL AODs. Taking into account the urban pollution of Athens, the CIMEL AODs should reach higher values than the model estimations that account only for transported dust. Indeed, just taking the mean of $\left(\mathrm{AOD}_{\text {cimel }}-\mathrm{AOD}_{\text {dream }}\right)$ of all measurements we can find an AOD equal with $0.10 \pm 0.07$ that can be attributed to the mean anthropogenic contribution in AOD during the period of this event. For three cases during this event the anthropogenic pollution contribution was found as high as 0.4 to 0.6 .

To further evaluate the model, we proceed with an intercomparison of modelled vertical profile of extinction at $550 \mathrm{~nm}$ with Raman lidar-derived vertical profile of extinction at $532 \mathrm{~nm}$ for 20 August at 18:00 UTC, when correlative

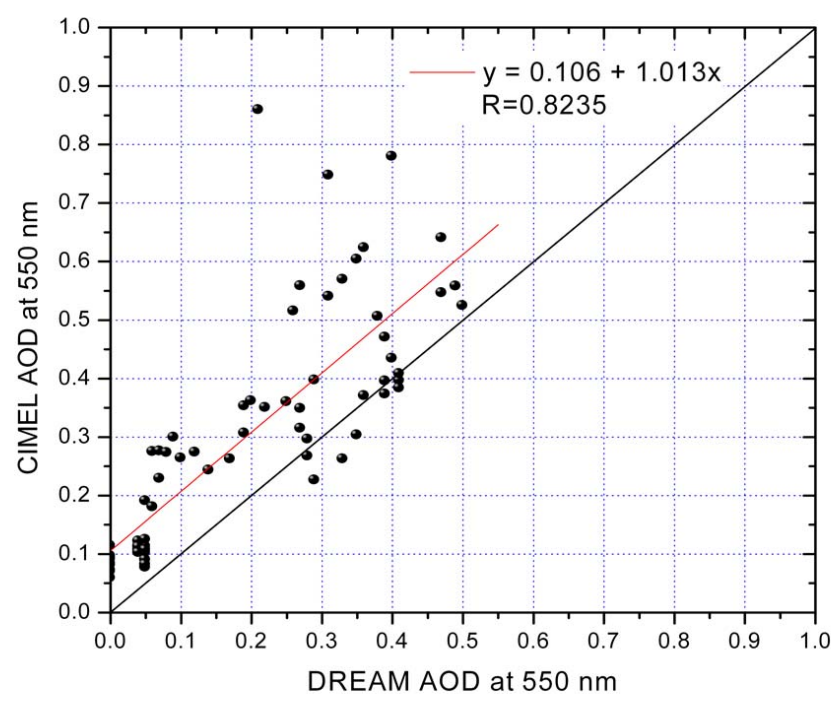

Fig. 6. CIMEL versus BSC-DREAM AODs at $550 \mathrm{~nm}$ for dust cases observed within the period between 18-23 of May 2008.

Raman lidar and model data were available (Fig. 7). Profiles are plotted for the complete overlap height region of NTUA's lidar $(>800 \mathrm{~m})$. Time averaging of lidar signals was performed for $\sim 60 \mathrm{~min}$ (17:25-18:38 UTC) around the exact time that the model delivers vertical profiles of the extinction (18:00 UTC). Vertical sliding average of the lidar extinction was performed around model height levels. From Fig. 7 it is evident that the dust layer is clearly lying between $2067-5135 \mathrm{~m}$ according to both lidar and model. Radiosonde measurements over Athens at 12:00 UTC showed a PBL height of the order of $1845 \mathrm{~m}$ (not shown here) while lidar derived aerosol layer height at the time of our Raman lidar measurements found at $1975 \mathrm{~m}$. Considering that PBL is below $2000 \mathrm{~m}$, the differences between lidar measurements of extinction and model estimations in Fig. 7 are mainly attributed to the presence of anthropogenic pollution. The 


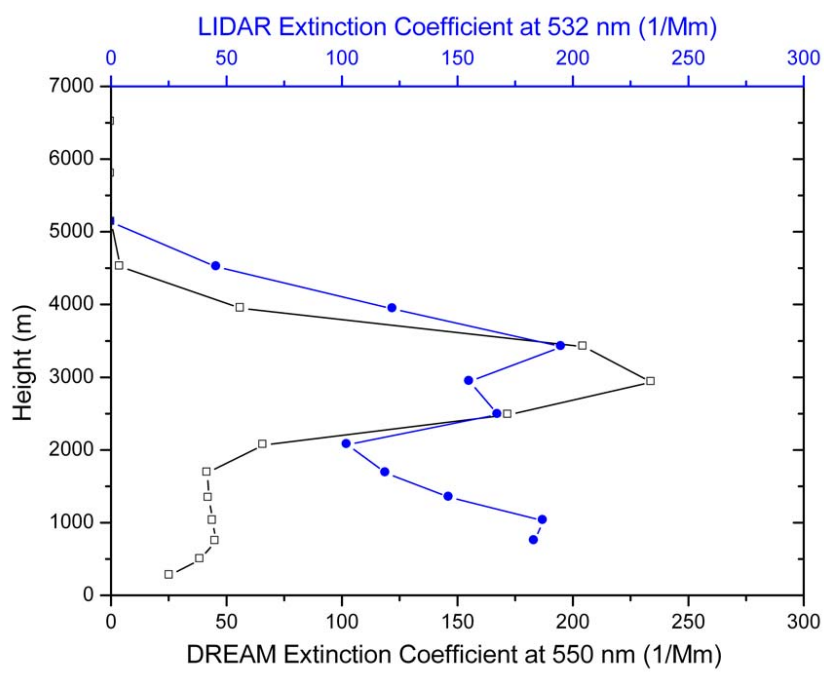

Fig. 7. Comparison of extinction coefficient profile simulated by BSC-DREAM at $550 \mathrm{~nm}$ (only for dust) and observed by Raman lidar measurements at $532 \mathrm{~nm}$ over Athens, on 20 May 2008 at 18:00 UTC. Raman lidar signals were averaged between 17:25 and 18:38 UTC.

model follows well the vertical distribution of the dust layer for the free troposphere since it provides extinction coefficients for dust particles only. Within the PBL, model estimates a dust contribution much lower than that of the free troposphere. The agreement between lidar and model results in the free troposphere could be considered as excellent, keeping in mind that Raman lidar extinction retrieval uncertainties are of the order of $15-30 \%$.

Model's capability to estimate the dust layer geometrical and optical characteristics, is evaluated by the calculation of the center of mass and the AOD. The calculations are performed within the dust layer as estimated above (2067$5135 \mathrm{~m}$ ), in order to remove the anthropogenic effect. The center of mass $(\mathrm{CM})$ altitude $\left(z_{c}\right)$ from the extinction is calculated as follows (Mona et al., 2006):

$z_{c}=\frac{\int_{z_{b}}^{z_{t}} z \cdot \operatorname{ext}(z) d z}{\int_{z_{b}}^{z_{t}} \operatorname{ext}(z) d z}$

where $\operatorname{ext}(z)$ represents the extinction coefficient at 532 and $550 \mathrm{~nm}$ for lidar and the model respectively, while $z_{b}$ and $z_{t}$ represent the bottom $(2067 \mathrm{~m})$ and top $(5135 \mathrm{~m})$ height of the dust layer. According to our calculations, the CM from the model is estimated at $3054 \mathrm{~m}$ while our lidar measurements locate $\mathrm{CM}$ at $3234 \mathrm{~m}$. The difference of $180 \mathrm{~m}$ can be attributed to the extinction minimum observed with lidar at $3000 \mathrm{~m}$, which is not predicted by the model. Specifically, maximum extinction coefficients reached $234 \mathrm{Mm}^{-1}$ according to the model at $2933 \mathrm{~m}$ and $195 \mathrm{Mm}^{-1}$ at $3420 \mathrm{~m}$ according to lidar. Considering AODs within the dust layer, the differences between the model (0.34) and lidar (0.36) are of the order of $-6 \%$. Our results indicate that generally, BSCDREAM's deviations from measured lidar geometrical and optical characteristics are within the error of lidar measurements and model's performance for the presented Saharan dust outbreak could be considered excellent.

\section{Summary and conclusions}

The spatial and temporal evolution, optical properties and vertical structure of the Saharan dust plume that affected Europe between 18-23 May 2008 were analyzed in detail over Greece using synergistic passive and active remote sensing techniques together with BSC-DREAM dust modeling simulations. The main results and conclusions are summarized as follows: Comparisons of modeled and measured aerosol optical depths over Athens show that the Saharan dust episode is well simulated by BSC-DREAM simulations, both spatially and temporarily. Direct comparison of CIMEL-BSCDREAM AODs showed an agreement with a correlation coefficient of the order of 0.8. Model vertical distribution estimations of the extinction coefficient are in very good agreement with Raman lidar measurements in the free troposphere of Athens on 20 May 2008. BSC-DREAM-lidar intercomparisons of the geometrical and optical characteristics of dust were studied only in the height ranges where the data indicate the presence of dust particles. Following this approach, the model simulations of the layer thickness, bottom and top height, AOD and center of mass are in very good agreement with lidar ground-based measurements. The model showed better performance when compared with lidar measurements than those revealed from sunphotometric observations. This is attributed to the fact that in lidar measurements the comparison of the extinction is feasible for selected atmospheric layers in the free troposphere where dust prevails than aerosol particles of anthropogenic origin.

Acknowledgements. We acknowledge support by the NASA GEChri grant NNX06AF30G and by the technical officers Don Anderson and Lucia Tsaoussi. The support of Academy of Athens which hosts the CIMEL sunphotometer is greatly acknowledged. The financial support for EARLINET (EARLINET-ASOS) by the European Commission under grant RICA-025991 and the European Space agency (ESA-AO/1-5502/07/NL/HE) are gratefully acknowledged. CALIPSO and MODIS data were obtained from the NASA Langley Research Center Atmospheric Science Data Center. SK would like to acknowledge the Marie Curie Intra European fellowship "Validation of Aerosol optical Properties and surface Irradiance measured from Ozone Monitoring Instrument on board of AURA satellite" VAP-OMI, AOR A/119693 - PIEF-GA-2008219908. REM and EG acknowledge the support of the PENED project (03-ED-169 and 03-ED-344, respectively). The PENED 2003 project is co-financed $75 \%$ of Public expenditure through EC European Social Fund and 25\% of Public expenditure through Ministry of Development, General Secretariat of Research and development and through private sector (Raymetrics SA.), under Measure 
8.3 of OPERATIONAL PROGRAMME "COMPETITIVE-NESS" in the 3rd Community Support Programme.

Topical Editor F. D'Andrea thanks four anonymous referees for their help in evaluating this paper.

\section{References}

Amiridis V., Balis, D., Kazadzis S., Giannakaki, E., Papayannis, A., and Zerefos, C.: Four years aerosol observations with a Raman lidar at Thessaloniki, Greece, in the framework of European Aerosol Research Lidar Network (EARLINET), J. Geophys. Res., 110, D21203, doi:10.1029/2005JD006190, 2005.

Ansmann A., Bösenberg, J., Chaikovsky, A., Comerón, A., Eckhardt, S., Eixmann, R., Freudenthaler, V., Ginoux, P., Komguem, L., Linné, H., Márquez, M. Á. L., Matthias, V., Mattis, I., Mitev, V., Müller, D., Music S., Nickovic, S., Pelon, J., Sauvage, L., Sobolewsky, Srivastava, M. K., Stohl, A., Torres, O., Vaughan, G., Wandinger, U., and Wiegner, M., Long-range transport of Saharan dust to northern Europe: The 11-16 October 2001 outbreak observed with EARLINET, J. Geophys. Res., 108(D24), 4783, doi:10.1029/2003JD003757, 2003.

Ansmann, A., Wandinger, U., Riebesell, M., Weitkamp, C., and Michaelis, W.: Independent measurement of extinction and backscatter profiles in cirrus clouds by using a combined Raman elastic backscatter lidar, Appl. Optics, 31, 7113-7131, 1992.

Balis, D. S., Amiridis, V., Zerefos, C., Kazantzidis, A., Kazadzis, S., Bais, A. F., Meleti, C., Gerasopoulos, E., Papayannis, A., Matthias, V., Dier, H., and Andreae, M. O.: Study of the effect of different type of aerosols on UV-B radiation from measurements during EARLINET, Atmos. Chem. Phys., 4, 307-321, 2004, http://www.atmos-chem-phys.net/4/307/2004/.

Balis D., Amiridis, V., Nickovic, S., Papayannis, A., and Zerefos, C.: Optical properties of Saharan dust layers as detected by a Raman lidar at Thessaloniki, Greece, Geophys. Res. Lett., 31, L13104, doi:10.1029/2004GL019881, 2004.

Böckmann, C., Wandinger, U., Ansmann, A., Bösenberg, J., Amiridis, V., Boselli, A., Delaval, A., De Tomasi, F., Frioud, M., Grigovov, I. V., Hagard, A., Iarlori, M., Komguem, L., Kreipl, S., Larcheveque, G., Matthias, V., Papayan-nis, A., Pappalardo, G., Rocadenbosch, F., Rodrigues, J. A., Schneider, J., Scherbakov, V., and Wieger, M.: Aerosol lidar intercomparison in the framework of the EARLINET project: 2. Aerosol backscatter algorithms, Appl. Optics, 43, 977-989, 2004.

Bösenberg, J., Matthias, V., Amodeo, A., Amoiridis, V., Ansmann, A., et al.: EARLINET project: A European Aerosol Research Lidar Network, Max-Planck Institute (MPI), Final Report, 348, 1-250, 2003.

Dubovik, O., Holben, B. N., Eck, T. F., Smirnov, A., Kaufman, Y. J., King, M. D., Tanre, D., and Slutsker, I.: Variability of absorption and optical properties of key aerosol types observed in worldwide locations, J. Atmos. Sci., 59, 590-608, doi:10.1175/15200469, 2002.

Dubovik, O., Sinyuk, A., Lapyonok, T., Holben, B. N., Mishchenko, M., Yang, P., Eck, T. F., Volten, H., Munõz, O., Veihelmann, B., van der Zande, W. J., Leon, J. F., Sorokin, M., and Slutsker, I.: Application of spheroid models to account for aerosol particle nonsphericity in remote sensing of desert dust, J. Geophys. Res., 111, D11208, doi:10.1029/2005JD006619, 2006.
Eck, T. F., Holben, B. N., Reid, J. S., Dubovik, O., Smirnov, A., O'Neill, N. T., Slutsker, I., and Kinne S.: The wavelength dependence of the optical depth of biomass burning, urban and desert dust aerosols, J. Geophys. Res., 104, 31333-31350, 1999.

Fécan, F., Marticorena, B., and Bergametti, G.: Parametrization of the increase of the aeolian erosion threshold wind friction velocity due to soil moisture for arid and semi-arid areas, Ann. Geophys., 17, 149-157, 1999, http://www.ann-geophys.net/17/149/1999/.

Formenti, P., Andreae, M. O., Andreae, T. W., Galani, E., Vasaras, A., Zerefos, C., Amiridis, V., Orlovsky, L., Karnieli, A., Wendisch, M., Wex, H., Holben, B. N., Maenhaut W., and Lelieveld, J.: Aerosol optical properties and large scale transport of air masses: Observations at a coastal and a semiarid site in the eastern Mediterra-nean during summer 1998, J. Geophys. Res., 106, 9807-9826, 2001.

Fotiadi, A., Hatzianastassiou, N., Drakakis, E., Matsoukas, C., Pavlakis, K. G., Hatzidimitriou, D., Gerasopoulos, E., Mihalopoulos, N., and Vardavas, I.: Aerosol physical and optical properties in the Eastern Mediterranean Basin, Crete, from Aerosol Robotic Network data, Atmos. Chem. Phys., 6, 53995413, 2006, http://www.atmos-chem-phys.net/6/5399/2006/.

Gerasopoulos, E., Andreae, M. O., Zerefos, C. S., Andreae, T. W., Balis, D., Formenti, P., Merlet, P., Amiridis, V., and Papastefanou, C.: Climatological aspects of aerosol optical properties in Northern Greece, Atmos. Chem. Phys., 3, 2025-2041, 2003, http://www.atmos-chem-phys.net/3/2025/2003/.

Giorgi, F.: A particle dry-deposition parameterization scheme for use in tracer transport models, J. Geophys. Res., 91, 9794-9804, 1986.

Holben, B. N., Eck, T. F., Slutsker, I., Tanre, D., Buis, J. P., Setzer, A., Vermote, E., Reagan, J. A., Kaufman, Y. J., Nakajima, T., Lavenu, F., Jankowiak, I., and Smirnov, A.: AERONET-A federated instrument network and data archive for aerosol characterization, Remote Sens. Environ., 66(1), 1-16, doi:10.1016/S0034-4257(98)00031-5, 1998.

Hostetler, C. A., Liu, Z., and Reagan, J.: CALIOP Algorithm Theoretical Basis Document, Calibration and Level 1 Data Products, Document No. PC-SCI-201, NASA, 2006.

Janjic, Z. I.: The Step-Mountain Eta Coordinate Model: Further Developments of the Convection, Viscous Sublayer, and Turbulence Closure Schemes, Mon. Weather Rev., 122, 927-945, 1994.

Kalivitis, N., Gerasopoulos, E., Vrekoussis, M., et al.: Dust transport over the eastern Mediterranean derived from Total Ozone Mapping Spectrometer, Aerosol Robotic Network, and surface measurements, J. Geophys. Res., 112(D3), D03202, doi:10.1029/2006JD007510, 2007.

Kallos, G., Nickovic, S., Papadopoulos, A., Jovic, D., Kakaliagou, O., Misirlis, N., Boukas, L., Mimikou, N., Sakellaridis, G., Papageorgiou, J., Anadranistakis, E., and Manousakis, M.: The regional weather forecasting system SKIRON: An overview, paper presented at the International Symposium on Regional Weather Prediction on Parallel Computer Environments, University of Athens, Athens, Greece, 15-17 October 1997.

Kazadzis, S., Bais, A., Amiridis, V., Balis, D., Meleti, C., Kouremeti, N., Zerefos, C. S., Rapsomanikis, S., Petrakakis, M., Kelesis, A., Tzoumaka, P., and Kelektsoglou, K.: Nine years of UV aerosol optical depth measurements at Thessaloniki, Greece, Atmos. Chem. Phys., 7, 2091-2101, 2007, 
http://www.atmos-chem-phys.net/7/2091/2007/.

Lelieveld, J., Berresheim, H., Borrmann, S., Curtzen, P. J, Dentener, F. J., Fischser, H., Feichter, J., Flatau, P. J., Hegland, J., Holzinger, R., Korrmann, R., Lawrence, M. G., Levin, Z., Karkowicz, K. M., Mihalopoulos, N., Minikin, A., Ramanathan, V., de Reus, M., Roelofs, G. J., Scheeren, H. A., Sciare, J., Schlager, H., Schultz, M., Sieg-mund, P., Steil, B., Stephanou, E. G., Stier, P., Traub, M., Warneke, C., Williams, J., and Ziereis, H.: Global Air Pollution Crossroads over the Mediterranean, Science, 298, 794-799, 2002.

Mamouri, R. E., Amiridis, V., Papayannis, A., Giannakaki, E., Tsaknakis, G., and Balis, D. S.: Validation of CALIPSO spaceborne-derived aerosol vertical structures using a ground-based lidar in Athens, Greece, Atmos. Meas. Tech. Discuss., 2, 561-587, 2009, http://www.atmos-meas-tech-discuss.net/2/561/2009/.

Matthias, V., Freudenthaler, V., Amodeo, A., Balin, I., Balis, D., Bösenberg, J., Chaikovsky, A., Chourdakis, G., Comeron, A., Delaval, A., de Tomasi, F., Eixmann, R., Hagard, A., Komguem, L., Kreipl, S., Matthey, R., Rizi, V., Rodrigues, J. A., Wandinger, U., and Wang, X.: Aerosol Lidar Intercomparison in the framework of EARLINET project. 1. Instruments, Appl. Optics, 43, 961-976, 2004

Mattis, I., Ansmann, A., Müller, D., Wandinger, U., and Althausen, D.: Dual wavelength Raman lidar observations of the extinctionto-backscatter ratio of Saharan dust, Geophys. Res. Lett., 29(9), 1306, doi:10.1029/2002GL014721, 2002.

Mihalopoulos, N., Stephanou, E., Kanakidou, M., Pilitsidis, S., and Bousquet, P.: Tropo-spheric aerosol ionic composition in the eastern Mediterranean region, Tellus B, 49, 314-326, 1997.

Mona, L., Amodeo, A., Pandolfi, M., and Pappalardo, G.: Saharan dust intrusions in the Mediterranean area: Three years of Raman lidar measurements, J. Geophys. Res., 111, D16203, doi:10.1029/2005JD006569, 2006.

Nickovic, S., Papadopoulos, A., Kakaliagou, O., and Kallos, G.: Model for prediction of desert dust cycle in the atmosphere, J. Geophys. Res., 106, 18113-18129, 2001.

Papayannis, A., Balis, D., Amiridis, V., Chourdakis, G., Tsaknakis, G., Zerefos, C., Castanho, A. D. A., Nickovic, S., Kazadzis, S., and Grabowski, J.: Measurements of Saharan dust aerosols over the Eastern Mediterranean using elastic backscatter-Raman lidar, spectrophotometric and satellite observations in the frame of the EARLINET project, Atmos. Chem. Phys., 5, 2065-2079, 2005, http://www.atmos-chem-phys.net/5/2065/2005/.

Papayannis, A., Amiridis, V., Mona, L., et al.: Systematic lidar observations of Saharan dust over Europe in the frame of EARLINET (2000-2002), J. Geophys. Res., 113, D10204, doi:10.1029/2007JD009028, 2008.
Pappalardo, G., Almodeo, A., Pandolfi, M., Wandinger, U., Ansmann, A., Bösenberg, J., Matthias, V., Amiridis, V., De Tomasi, F., Frioud, M., Iarlori, M., Komguem, L., Papayannis, A., Rocadenbosch F., and Wang, X.: Aerosol inter-comparison in the framework of EARLINET project: 3. Raman lidar algorithm for aerosol extinction, backscatter, and lidar ratio, Appl. Optics, 43, 5370-5385, 2004.

Pérez, C., Nickovic, S., Pejanovic, G., Baldasano, J. M., and Özsoy, E.: Interactive dust-radiation modeling: A step to improve weather forecasts, J. Geophys. Res., 111, D16206, doi:10.1029/2005JD006717, 2006a.

Pérez, C., Nickovic, S., Baldasano, J. M., Sicard, M., Rocadenbosch, F., and Cachorro, V. E.: A long Saharan dust event over the western Mediterranean: Lidar, Sun photometer observations, and regional dust modeling, J. Geophys. Res., 111, D15214, doi:10.1029/2005JD006579, 2006b.

Remer, L., Kleidman, R., Levy, R., Kaufman, Y., Tanré, D., Mattoo, S., Martins, J. V., Ichoku, C., Koren, I., Yu, H., and Holben, B.: Global aerosol climatology from the MODIS satellite sensors, L. Geophys. Res., 113, D14S07, doi:10.1029/2007JD009661, 2008.

Shao, Y., Raupach, M. R., and Findlater, P. A.: Effect of saltation bombardment on the entrainment of dust by wind, J. Geophys. Res., 98(D7), 12719-12726, 1993.

Sokolik, I. N., Winker, D. M., Bergametti, G., Gillette, D. A., Carmichael, G., Kaufman, Y. J., Gomes, L., Schuetz, L., and Penner, J. E.: Introduction to special section: Outstanding problems in quantifying the radiative impacts of mineral dust, J. Geophys. Res., 106, 18015-18027, 2001.

Whiteman, D. N., Melfi, S. H., and Ferrare, R. A.: Raman lidar system for the measurement of 30 water vapor and aerosols in the Earth's atmosphere, Appl. Optics, 31, 3068-3081, 1992.

Winker, D., Vaughan, M., and Hunt, W.: The CALIPSO mission and initial results from CALIOP, Proc. SPIE, 6409, 640902, doi:10.1117/12.698003, 2006.

Zerefos, C. S., Kourtidis, K. A., Melas, D., Balis, D., Zanis, P., Mantis, H. T., Repapis, C., Isaksen, I., Sundet, J., Herman, J., Bhartia, P. K., and Calpini, B.: Photochemical Activity and Solar Ultraviolet Radiation Modulation Factors (PAUR): An overview of the project, J. Geophys. Res., 107(D18), 8134, doi:10.1029/2000JD000134, 2002. 